\title{
The Role of Undifferentiated Connective Tissue Dysplasia in the Development and Clinic of Non-Traumatic Subarachnoid Hemorrhage
}

\author{
Shchepankevich LA ${ }^{1,2 *}$, Petrova EV ${ }^{2}$, Gribacheva $\mathrm{IA}^{2}$, Popova $\mathrm{TF}^{2}$, Novikova EG ${ }^{1}$ and Pervuninskaya $\mathrm{MA}^{1}$ \\ ${ }^{1}$ Federal State Budgetary Scientific Institution, Federal Research Center of Fundamental and Translational Medicine, Novosibirsk, Russia \\ ${ }^{2}$ Neurology Department, Federal State Budgetary Educational Institution, Novosibirsk State Medical University, Novosibirsk, Russia
}

*Corresponding author: Shchepankevich LA, Neurology Department, Federal State Budgetary Educational Institution, Novosibirsk State Medical University, Novosibirsk, Russia

\begin{abstract}
Objectives: Assessments of the clinical manifestations of undifferentiated connective tissue dysplasia (UCTD) can help for early diagnosis with the definition of the characteristics and prognosis of the subarachnoid hemorrhage (SAH) with the definition of further correct management and preventive measures.

Materials and Methods: we study a group of patients with non-traumatic subarachnoid hemorrhage (n=165) who were admitted at the Stroke Unit \#1 in Novosibirsk (Russia) from 2013 till 2017 years. The dysplastic structure of the cerebral vessels and the peculiarities of the craniovertebral junction were assessed by CT angiography, USDG, R-graphy of the skull, and brain MRI.

Results: The evaluation of the clinical, constitutional anatomical, radiology and ultrasound parameters showed that determine the development of non-traumatic subarachnoid hemorrhage of aneurysmal origin in young people are combined with stigmas of undifferentiated connective tissue dysplasia.

Conclusion: The analysis of clinical features of patients with non-traumatic subarachnoid hemorrhage and undifferentiated connective tissue dysplasia provides information that finding of stigma of dysembryogenesis can be early signals of cerebral vessels pathology.
\end{abstract}

Keywords: Undifferentiated Connective Tissue Dysplasia; Non-Traumatic Subarachnoid Hemorrhage

\section{Introduction}

Some researches of recent years have described the changes in cerebral vessels with idiopathic expansion of the wall of elastic arteries with the formation of an aneurysm, pathological kinking, loop formation [1-3], as a manifestation of a systemic dysplastic process. Assessments of the clinical manifestations of undifferentiated connective tissue dysplasia (UCTD) can help for early diagnosis with the definition of the characteristics and prognosis of the subarachnoid hemorrhage (SAH) with the definition of further correct management and preventive measures $[1,4,5]$. The connective tissue is a basic sort of tissue providing structural and metabolic support for other organs and tissues the body. It is different, compared to other tissues, consists in its composition of a diverse set of components - cells, fibers, blood vessels - scattered throughout the extracellular matrix. Hereditary connective tissue diseases are among the most common human genetic diseases. However, undifferentiated connective tissue dysplasia is not always detected in persons with cerebrovascular pathology, especially with non-traumatic subarachnoid hemorrhage $[4,5]$.

Aim of Study: To systematize and characterize the main and additional risk factors for non-traumatic subarachnoid hemorrhage in young people to create a complete system of preventive measures. 
Materials and Methods: To achieve this goal we have collected a group of patients with subarachnoid hemorrhage ( $n=165)$ who were admitted and treated at the Stroke Unit \#1 in Novosibirsk (Russia) from 2013 till 2017 years. There were 76 (46.1\%) men and 89 (53.9\%) women, mean age was $48.82 \pm$ 5.29 years old $[\mathrm{Me}=44 ; \mathrm{Mo}=60$; K-S $\mathrm{p}<0,01$; Lilliefors $\mathrm{p}<0,01]$. We evaluated the clinic and anamnesis with the identification of vascular risk factors, determination of comorbidity, neurology examination, brain CT and CT brain angiography, lumbar puncture, transcranial Doppler sonography, ultrasound examination of the head and neck vessels. The dysplastic structure of the cerebral vessels and the peculiarities of the craniovertebral junction were assessed by CT angiography, USDG, R-graphy of the skull, and brain MRI.

Exclusion Criteria: Necessary of neurosurgical treatment, decompensated concomitant somatic pathology (heart failure; diseases of the lungs, liver and kidneys, blood diseases; neoplastic processes; severe diabetes mellitus, hypothyroidism, thyrotoxicosis and others).

To test statistical hypotheses about the differences in relative frequencies, mean values of a trait in two independent samples, the Mann-Whitney test, a two-sided Fisher's exact test, was used. In all procedures of statistical analysis, the achieved level of significance (p) was calculated, the critical level of significance was taken equal to 0.05 . The odds ratio (OR), its significance (p) and confidence limits $(-95 \% \mathrm{CL} ;+95 \% \mathrm{CL})$ - statistically significant OR values greater than 1 indicated an increase in the chances of a successful outcome, and less than 1 - a decrease in this chance under the influence of this factor.

Results and Discussion: The data of CT angiography and USDG were analyzing, we attended the structural features of the vascular system of the brain. The variants of the structure of cerebral vessels in patients with SAH is presented in (Table 1).

Table 1: The variants of the structure of cerebral vessels in patients with SAH.

\begin{tabular}{|c|c|c|c|c|c|c|}
\hline \multirow{6}{*}{$\begin{array}{l}\text { Options vascular } \\
\text { structure }\end{array}$} & \multirow{2}{*}{\multicolumn{3}{|c|}{$\begin{array}{l}\text { Groups } \\
\mathrm{N}=165\end{array}$}} & \multirow{2}{*}{\multicolumn{3}{|c|}{$\begin{array}{c}\text { p (between groups) (Fisher exact } p, \text { two-tailed as amended } \\
\text { by Bonferroni) }\end{array}$}} \\
\hline & & & & & & \\
\hline & Young Age & Middle Age & Elderly Age & \multirow{4}{*}{$1-2$} & \multirow{4}{*}{$1-3$} & \multirow{4}{*}{$2-3$} \\
\hline & $25-44$ & $44-60$ & $60-75$ & & & \\
\hline & $n=93$ & $n=25$ & $\mathrm{n}=47$ & & & \\
\hline & $\{1\}$ & $\{2\}$ & $\{3\}$ & & & \\
\hline \multirow{2}{*}{$\begin{array}{l}\text { Vascular } \\
\text { Hypoplasia }\end{array}$} & 81 & 8 & 2 & \multirow{2}{*}{$<0.0001$} & \multirow{2}{*}{$<0.0001$} & \multirow{2}{*}{$<0.0001$} \\
\hline & $87.1 \%$ & $32.0 \%$ & $4.3 \%$ & & & \\
\hline \multirow{2}{*}{ Vascular Aplasia } & 72 & 8 & 1 & \multirow{2}{*}{$<0.0001$} & \multirow{2}{*}{$<0.0001$} & \multirow{2}{*}{$<0.0001$} \\
\hline & $77.4 \%$ & $32.0 \%$ & $2.1 \%$ & & & \\
\hline \multirow{2}{*}{$\begin{array}{l}\text { Pathological } \\
\text { Tortuosity }\end{array}$} & 93 & 11 & 14 & \multirow{2}{*}{$<0.0001$} & \multirow{2}{*}{$<0.0001$} & \multirow{2}{*}{$<0.0001$} \\
\hline & $100 \%$ & $44.0 \%$ & $29.8 \%$ & & & \\
\hline \multirow{2}{*}{ Kinking } & 69 & 13 & 35 & \multirow{2}{*}{0.0653} & \multirow{2}{*}{0.9890} & \multirow{2}{*}{0.0651} \\
\hline & $74.2 \%$ & $52.0 \%$ & $74.5 \%$ & & & \\
\hline \multirow{2}{*}{ Koyling } & 63 & 11 & 31 & \multirow{2}{*}{0.0687} & \multirow{2}{*}{0.9872} & \multirow{2}{*}{0.0712} \\
\hline & $67.7 \%$ & $44.0 \%$ & $65.9 \%$ & & & \\
\hline \multirow{2}{*}{$\begin{array}{l}\text { Incomplete Circle } \\
\text { of Willis }\end{array}$} & 66 & 7 & 1 & \multirow{2}{*}{$<0.0001$} & \multirow{2}{*}{$<0.0001$} & \multirow{2}{*}{$<0.0001$} \\
\hline & $70.9 \%$ & $28.0 \%$ & $2.1 \%$ & & & \\
\hline \multirow{2}{*}{$\begin{array}{l}\text { Atherosclerotic } \\
\text { Lesion of Cerebral } \\
\text { Vessels }\end{array}$} & 2 & 13 & 47 & \multirow{2}{*}{$<0.0001$} & \multirow{2}{*}{$<0.0001$} & \multirow{2}{*}{$<0.0001$} \\
\hline & $2.2 \%$ & $52.0 \%$ & $100 \%$ & & & \\
\hline
\end{tabular}

Pathology changes in cerebral vessels were found in all groups, but in the group of young patients, in contrast to the older age group were found hypoplasia, aplasia, pathological tortuosity, as well as an incomplete circle of Willis. These finding were significantly more common and indicated to congenital dysplastic changes. Kinking and koyling vessel deformation were found in all the examined groups, but they had different origins: dysplastic changes - in young people, atherosclerotic - in the older age group. This does not contradict the data published Kim MS and alt, Cornelissen BMW and alt $[6,7]$.

After revealing the dysplastic structure of the cerebral vessels, the research was continued to assess other stigmas of dysembryogenesis. An examination of the craniovertebral junction was performed and revealed changes such as platybasia, manifestation of the occipital vertebrae, and basilar impression. Suboccipital changes also were found, represented by the 
formation of Kimmerle bony bridges (55.2\%), concrescence of two cervical vertebrae (17.6\%) and aplasia (hypoplasia) of the dens Axis (12.7\%). Revealed changes were presented in different age groups in different ways. In the group of young patients, both occipital and suboccipital changes occurred significantly more often in comparison with the middle age group and especially with the elder one (Table 2).

Table 2: Changes in the craniovertebral junction in patients with SAH in different age groups.

\begin{tabular}{|c|c|c|c|c|c|c|}
\hline \multirow{6}{*}{ Signs } & \multicolumn{3}{|c|}{ Groups } & \multirow{2}{*}{\multicolumn{3}{|c|}{$\begin{array}{c}\text { p (between groups) (Fisher exact p, two-tailed as amended } \\
\text { by Bonferroni) }\end{array}$}} \\
\hline & \multicolumn{3}{|c|}{$N=165$} & & & \\
\hline & Young Age & Middle Age & Elderly Age & \multirow{4}{*}{$1-2$} & \multirow{4}{*}{$1-3$} & \multirow{4}{*}{$2-3$} \\
\hline & $25-44$ & $44-60$ & $60-75$ & & & \\
\hline & $\mathrm{n}=93$ & $n=25$ & $\mathrm{n}=47$ & & & \\
\hline & $\{1\}$ & $\{2\}$ & $\{3\}$ & & & \\
\hline \multicolumn{7}{|c|}{ Occipital changes } \\
\hline \multirow{2}{*}{ Platybasia } & 59 & 7 & 7 & \multirow{2}{*}{$<0.0001$} & \multirow{2}{*}{$<0.0001$} & \multirow{2}{*}{0.0074} \\
\hline & $63.4 \%$ & $28.0 \%$ & $14.9 \%$ & & & \\
\hline \multirow{2}{*}{ Basilar impression } & 14 & 3 & 5 & \multirow{2}{*}{$<0.0001$} & \multirow{2}{*}{$<0.0001$} & \multirow{2}{*}{0.4614} \\
\hline & $15.1 \%$ & $12.0 \%$ & $10.6 \%$ & & & \\
\hline \multirow{2}{*}{$\begin{array}{l}\text { manifestation of } \\
\text { occipital vertebrae }\end{array}$} & 46 & 3 & 4 & \multirow{2}{*}{$<0.0001$} & \multirow{2}{*}{$<0.0001$} & \multirow{2}{*}{0.0741} \\
\hline & $49.5 \%$ & $12.0 \%$ & $8.6 \%$ & & & \\
\hline \multicolumn{7}{|c|}{ Suboccipital changes } \\
\hline \multirow{2}{*}{$\begin{array}{l}\text { The formation of } \\
\text { the proatlas }\end{array}$} & 36 & 2 & 1 & \multirow{2}{*}{$<0.0001$} & \multirow{2}{*}{$<0.0001$} & \multirow{2}{*}{0.0345} \\
\hline & $38.7 \%$ & $8.0 \%$ & $2.1 \%$ & & & \\
\hline \multirow{2}{*}{ Atlas assimilation } & 18 & 1 & 0 & \multirow{2}{*}{$<0.0001$} & \multirow{2}{*}{$<0.0001$} & \multirow{2}{*}{0.0453} \\
\hline & $19.6 \%$ & $4.0 \%$ & $0.0 \%$ & & & \\
\hline \multirow{2}{*}{$\begin{array}{l}\text { Atlas anterior arch } \\
\text { clefts }\end{array}$} & 17 & 0 & 0 & \multirow{2}{*}{0.0012} & \multirow{2}{*}{$<0.0001$} & 1.0000 \\
\hline & $18.3 \%$ & $0.0 \%$ & $0.0 \%$ & & & 1.0000 \\
\hline Aplasia and & 20 & 1 & 0 & & & \\
\hline $\begin{array}{c}\text { hypoplasia of the } \\
\text { dens Axis }\end{array}$ & $21.5 \%$ & $4.0 \%$ & $0.0 \%$ & $<0.0001$ & $<0.0001$ & 0.0453 \\
\hline Odontoid hone & 13 & 0 & 0 & 00150 & 00230 & 10000 \\
\hline Udontold bone & $13.9 \%$ & $0.0 \%$ & $0.0 \%$ & 0.0150 & 0.0230 & 1.0000 \\
\hline Congenital fused & 26 & 2 & 1 & & & \\
\hline cervical vertebrae & $27.9 \%$ & $8.0 \%$ & $2.1 \%$ & $<0.0001$ & $<0.0001$ & 0.0345 \\
\hline A partial posterior & 84 & 3 & 4 & $<00001$ & $<00001$ & 0,0741 \\
\hline bridge & $90.3 \%$ & $12.0 \%$ & $8.6 \%$ & $<0.0001$ & $<0.0001$ & 0.0741 \\
\hline
\end{tabular}

In this way the young patient's pathology was more often detected as a partial posterior bridge (Kimmerle anomaly), platybasia, manifestation of occipital vertebrae. In the older age group, dysplastic changes were extremely rare, with platybasia and basilar impression predominating. We did not find any studies confirming the importance and necessity of searching for signals of connective tissue pathology and the relationship of these findings with the risk of developing SAH. However, the described pathological changes in cerebral vessels are associated with several pathological conditions that affect the patient's health $[7,8]$.

\section{Conclusion}

Thus, the constitutional anatomical and functional disorders that determine the development of non-traumatic subarachnoid hemorrhage of aneurysmal origin in young people with undifferentiated connective tissue dysplasia are: anomaly of the craniovertebral junction - a partial posterior bridge (Kimmerle anomaly) (90.3\%), platybasia (63.4\%), the manifestation of the occipital vertebrae $(49.5 \%)$, the formation of the proatlas (38.7\%) - [OR = $56.3(11,3 ; 281.6), \mathrm{p}<0.0001]$; dysplastic vascular structure - pathological tortuosity (100\%), hypoplasia $(87.1 \%)$, aplasia $(77.4 \%)$ - [OR = $77.1(9.2 ; 646.5), \mathrm{p}<0.0001]$; incomplete circle of Willis $(70.9 \%)-[\mathrm{OR}=24.6(7.4 ; 81.6), \mathrm{p}<0.0001]$, which statistically significantly differed from the indicators in the older age groups. The analysis of clinical features of patients with non-traumatic subarachnoid hemorrhage and undifferentiated connective tissue dysplasia provides information that finding of stigma of dysembryogenesis can be early signals of cerebral vessels pathology. 


\section{References}

1. Bamford J, Sandercock P, Dennis M, Burn J, Warlow C (1991) Classification and natural history of clinically identifiable subtypes of cerebral infarction. Lancet 337(8756): 1521-1526.

2. Bamford JM (2000) The role of the clinical examination in the subclassification of stroke. Cerebrovasc Dis 10 Suppl 4(4): 2-4.

3. Louis R Caplan (2009) Caplan's Stroke: A Clinical Approach. Elsevier Health Sciences. ISBN 978-1-4160-4721-6.
4. Amarenco P, Bogousslavsky J, Caplan LR, Donnan GA, Hennerici MG (2009) Classification of Stroke Subtypes. Cerebrovascular Diseases 27 (5): 493-501.

5. Ropper, Allan H, Adams, Raymond Delacy, Brown, et al. (2005) Adams and Victor's principles of neurology. New York, USA McGraw-Hill Medical Pub Division pp. 686-704.

\section{(c) (1) Commons Attribution 4.0 License}

To Submit Your Article Click Here: Submit Article

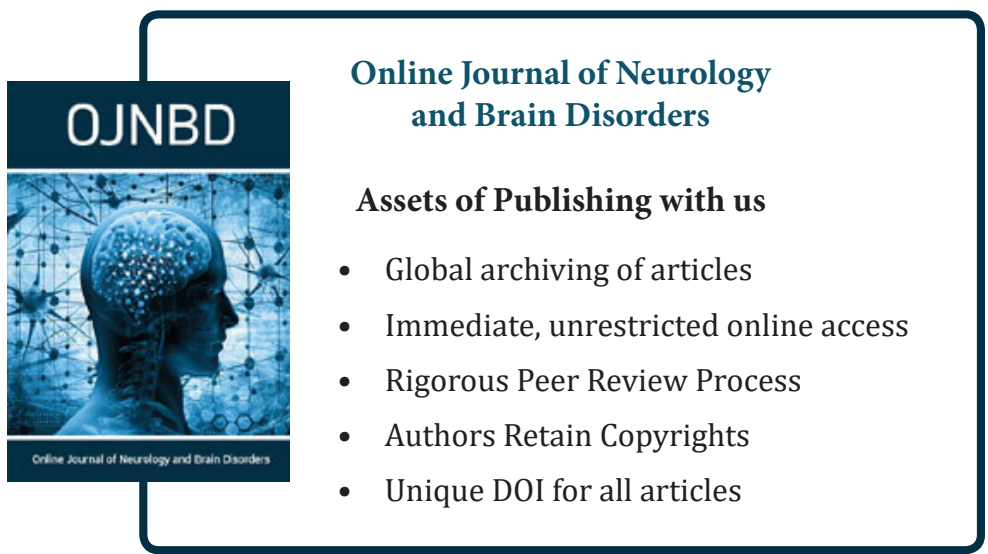

